A N N A L E S

UNIVERSITATIS MARIAE CURIE-SKŁODOWSKA

LUBLIN - POLONIA

VOL. LXXIV

SECTIO B

2019

MONIKA WIDZ

ORCID ID 0000-0003-3264-927X

Wydział Nauk o Ziemi i Gospodarki Przestrzennej

Uniwersytet Marii Curie-Skłodowskiej w Lublinie

monika.widz@umcs.pl

\title{
Ocena atrakcyjności infrastruktury turystycznej Tunezji metodą wielowymiarowej analizy porównawczej
}

Assessment of the attractiveness of Tunisia's tourist infrastructure by a multidimensional comparative analysis

\begin{abstract}
Tunisia belongs to popular destinations among the so-called organized mass tourists, for whom tourist infrastructure is an important initiator in a decision-making process of purchase. The aim of the study was to assess its attractiveness in quantitative terms in relation to the entire country and to individual governorates. This assessment was carried out as part of the adopted infrastructure components (bases: accommodation, catering, transport and complementary) by a multidimensional comparative analysis method. The adopted procedure allowed measurable comparison between 24 governorates as multi-feature objects using the summary feature index. The obtained results indicate that generally the tourist infrastructure of Tunisia is not very attractive. However, in the attractiveness of individual administrative units varies considerably. Infrastructure in the Tunis Governorate in the northern part of Tunisia was rated as the most attractive, while the least - the Al-Kasrajn Governorate in the western, mountainous area of the country. The obtained results also indicate the need for a better use of infrastructure in the Tunis Governorate, by preparing e.g. an offer addressed to mass tourists.
\end{abstract}

Keywords: attractiveness of tourism infrastructure, method of multidimensional comparative analysis, mass tourism, Tunisia

Abstrakt: Tunezja należy do destynacji popularnych wśród zorganizowanych turystów masowych, dla których ważnym czynnikiem w procesie podejmowania decyzji nabywczych jest infrastruktura turystyczna. Celem opracowania była ocena jej atrakcyjności w ujęciu ilościowym w odniesieniu do całego obszaru kraju oraz do poszczególnych gubernatorstw. Ocenę tę przeprowadzono w ramach przyjętych elementów składowych infrastruktury (baz: noclegowej, gastronomicznej, komunikacyjnej i towarzyszącej) metodą wielowymiarowej analizy porównawczej. Przyjęta procedura umożliwiła wymierne porównanie ze sobą 24 gubernatorstw jako obiektów wielocechowych przy wykorzystaniu sumarycznego wskaźnika cech. Uzyskane wyniki wskazują, że generalnie 
infrastruktura turystyczna Tunezji jest mało atrakcyjna. Natomiast w poszczególnych jednostkach administracyjnych jej atrakcyjność jest znacznie zróżnicowana. Jako najbardziej atrakcyjną oceniono infrastrukturę w gubernatorstwie Tunis w północnej części Tunezji, a najmniej - w gubernatorstwie Al-Kasrajn na zachodnim, górzystym obszarze kraju. Otrzymane rezultaty wskazują ponadto na konieczność lepszego wykorzystania infrastruktury w gubernatorstwie Tunis poprzez przygotowanie np. oferty skierowanej do turystów masowych.

Słowa kluczowe: atrakcyjność infrastruktury turystycznej, metoda wielowymiarowej analizy porównawczej, turystyka masowa, Tunezja

\section{WPROWADZENIE}

Tunezja od lat należy do najpopularniejszych destynacji wybieranych przez polskich turystów z racji zróżnicowanych zasobów środowiska geograficznego i szerokiej oferty turystycznej. Jest destynacją, w której od 1985 r. przeważa zorganizowana turystyka masowa (organized mass tourist) (Cohen 1972; Widz, Brzezińska-Wójcik 2016; Widz 2019). Według Niezgody (2013, s. 41): „Zorganizowany turysta masowy, który wykupuje pakiet turystyczny, preferuje pobyt w miejscowościach popularnych, w dużej grupie innych turystów, raczej nie poszukuje doświadczeń i przeżyć oryginalnych i ekstremalnych [...]”. W zaspokojeniu potrzeb turysty masowego (wypoczynek, rozrywka, przyjemności) ważną rolę odgrywa infrastruktura turystyczna. Istotnym czynnikiem dla konsumentów w procesie podejmowania decyzji nabywczych związanych z kierunkiem podróży jest zatem jej atrakcyjność.

W odniesieniu do turystyki atrakcyjność jest pojęciem złożonym, trudnym do jednoznacznego i w pełni zestandaryzowanego objaśnienia. Ogólnie atrakcyjność turystyczną definiuje się jako cechy obszaru, regionu, miejscowości lub pojedynczego obiektu, które wzbudzają zainteresowanie turystów (Kaczmarek i in. 2002) oraz wpływają na rozwój turystyki w określonej destynacji turystycznej lub pojedynczym obiekcie (Rapacz, Jaremen 2011). Natomiast według Page (1995) atrakcyjność turystyczną można rozumieć w trzech znaczeniach jako: 1) określaną przez różne klasyfikacje i/lub kategoryzacje (atrakcyjność ideograficzna), 2) wynikającą z przyjęcia określonej techniki jej oceniania, 3) wynik subiektywnego postrzegania. Oprócz obiektywnie istniejących walorów turystycznych i odpowiednich elementów infrastruktury turystycznej istotną rolę w wartościowaniu obiektu/obszaru odgrywa więc czynnik psychologiczny - subiektywne postrzeganie elementów infrastruktury przez turystów, inwestorów i mieszkańców (Warszyńska, Jackowski 1979; Kruczek 2011).

W geografii turyzmu ocena atrakcyjności mieści się w dwóch grupach tematycznych dotyczących 1) oceny przydatności przestrzeni turystycznej dla ruchu turystycznego oraz 2) procedur związanych z przestrzenną klasyfikacją 
zjawisk turystycznych na podstawie kryteriów zintegrowanych (Warszyńska, Jackowski 1979). W niniejszym opracowaniu skoncentrowano się na podejściu pierwszym, wpisując się w koncepcję realnej lub formalnej (Opperman 1993; Liszewski 1995) przestrzeni turystycznej.

Celem opracowania jest ilościowa ocena atrakcyjności infrastruktury turystycznej Tunezji, zarówno w ujęciu generalnym (całego obszaru kraju), jak i w ujęciu szczegółowym (w poszczególnych gubernatorstwach) w ramach przyjętych jej elementów składowych (ryc. 1) dla ruchu turystycznego. Porównanie uzyskanego obrazu ogólnego z obrazem szczegółowym ważne jest z punktu widzenia oceny zasobów z myślą o tworzeniu nowej oferty turystycznej skierowanej do turystów zorganizowanych (masowych).

\section{INFRASTRUKTURA TURYSTYCZNA W LITERATURZE PRZEDMIOTU}

Infrastruktura turystyczna, określana również jako ,zagospodarowanie turystyczne” lub „baza materialna turystyki”, tworzy zespół obiektów i urządzeń stanowiących wyposażenie określonego terenu, umożliwiających zaspokojenie potrzeb turystów (Warszyńska, Jackowski 1979; Wyrzykowski 2010; Krukowska, Krukowski 2013) oraz stabilizujących i normujących ruch turystyczny. W podobnym kierunku, tylko nieco szerzej, idą rozważania Kowalczyka i Derek (2010, s. 18), według których termin ,zagospodarowanie turystyczne” należy rozumieć jako „system połączonych ze sobą funkcjonalnie urządzeń turystycznych i usług (w niektórych przypadkach mogą to być jednak same urządzenia lub też same usługi), które występują na określonym obszarze [...] i które służą zaspokojeniu szeroko rozumianych potrzeb turystyczno-rekreacyjnych człowieka”. Infrastruktura turystyczna składa się z czterech komponentów: 1) bazy noclegowej, 2) bazy gastronomicznej (żywieniowej), 3) bazy komunikacyjnej (transportowej), 4) bazy towarzyszącej (uzupełniającej) (ryc. 1).

Baza noclegowa obejmuje wszelkiego rodzaju obiekty noclegowe, ich części lub części specjalnie dostosowanych środków transportowych, a także wyodrębnione tereny wraz z urządzeniami bezpośrednio związanymi z obsługą turystów (Milewska, Włodarczyk 2009). W literaturze przedmiotu (m.in. Rogalewski 1979; Warszyńska, Jackowski 1979; Gaworecki 2003; Milewski 2005; Kowalczyk, Derek 2010) bazę tę uznaje się za podstawowy element zagospodarowania turystycznego danego obszaru, a jej wielkość i strukturę uważa się za główne wskaźniki jego zdolności recepcyjnej.

Baza gastronomiczna (żywieniowa) w istotny sposób wpływa na kształtowanie się ruchu turystycznego, ponieważ głównym zadaniem obiektów 


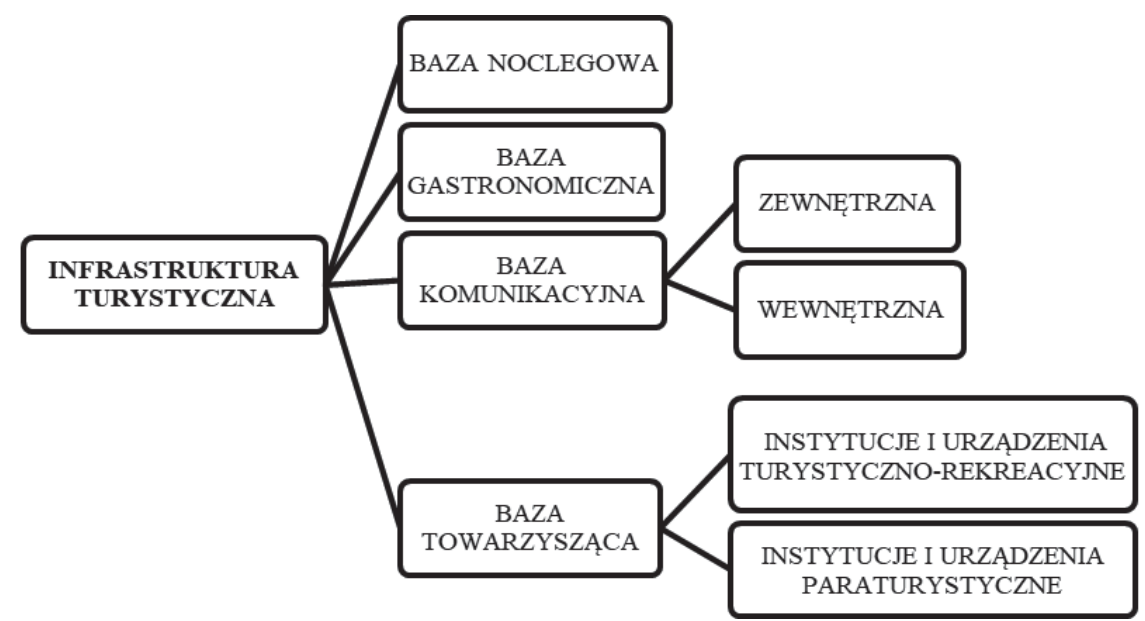

Ryc. 1. Składowe infrastruktury turystycznej

Źródło: opracowanie własne na podstawie (Rogalewski 1979; Pawlikowska-Piechotka 2009).

Fig. 1. Components of tourist infrastructure

Source: own study based on (Rogalewski 1979; Pawlikowska-Piechotka 2009).

wchodzących w jej skład jest zapewnienie wyżywienia turystom (Rogalewski 1979).

W literaturze przedmiotu podkreśla się ścisły związek pomiędzy transportem a turystyką (m.in. Rogalewski 1979; Page 2005; Duval 2007; Pawlusiński 2007; Kowalczyk, Derek 2010). Dynamiczny rozwój bazy komunikacyjnej, przekładający się na zmniejszenie kosztów i czasu podróży, przyczynił się do rozkwitu turystyki, która ze zjawiska elitarnego przeistoczyła się w zjawisko masowe. System komunikacji, na który składa się m.in. sieć i stan techniczny urządzeń (linie kolejowe, drogi, lotniska, porty morskie i śródlądowe), decyduje o stopniu dostępności terenów turystycznych (Rogalewski 1979). Dobrze rozwinięta infrastruktura transportowa powinna współgrać z pozostałymi składowymi bazy turystycznej i w sposób istotny wpływać na atrakcyjność danej jednostki terytorialnej. W Tunezji dostępność komunikacyjna składa się z dostępności zewnętrznej oraz dostępności wewnętrznej (Lijewski i in. 2002; Pawlusiński 2007).

Baza towarzysząca (uzupełniająca) obejmuje pozostałe obiekty, urządzenia i usługi umożliwiające realizację różnych form turystyki, wypoczynku i rekreacji (Rogalewski 1979). Mają one charakter usługowy, handlowy, rozrywkowy, kulturalny i sportowy (Kowalczyk 2002; Lijewski i in. 2002; Płocka 2002). Oprócz tego, że zaspokajają potrzeby turystów, bardzo często warunkują też rozwój funkcji turystycznej na określonym obszarze. Wyróżnia się dwie główne grupy obiektów należących do bazy uzupełniającej: 1) instytucje i urządzenia 
turystyczno-rekreacyjne służące zaspokajaniu potrzeb przede wszystkim turystów, a następnie umożliwiające stałym mieszkańcom danego obszaru/miejsca korzystanie z tych urządzeń podczas ich wypoczynku, oraz 2) instytucje i urządzenia paraturystyczne umożliwiające korzystanie z najszerszego zakresu usług związanych z codziennymi potrzebami stałych mieszkańców, z których mogą korzystać również turyści (Pawlikowska-Piechotka 2009).

\section{METODY BADAŃ I ŹRÓDŁA DANYCH}

Do określenia stopnia atrakcyjności zagospodarowania turystycznego Tunezji zastosowano taksonomiczną metodę wielowymiarowej analizy porównawczej zaadaptowaną za Gołembskim (red. 1999). Daje ona możliwość badania zjawisk złożonych, opisywanych za pomocą co najmniej dwóch (a przeważnie większej liczby) zmiennych (Borys 1980; Dziechciarz 2003). Do analizy infrastruktury turystycznej wykorzystano 32 cechy (tab. 1), wybrane z uwzględnieniem kwerendy literatury przedmiotu (Płocka 2002; Pawlikowska-Piechotka 2009; Kowalczyk, Derek 2010). Zostały one przypisane do poszczególnych kategorii (np. instytucje i urządzenia turystyczno-rekreacyjne) oraz podkategorii (np. urządzenia rozrywkowe) wchodzących w skład czterech działów: 1) bazy noclegowej, 2) bazy gastronomicznej, 3) bazy komunikacyjnej, 4) bazy towarzyszącej (ryc. 1, tab. 1).

W kompleksowej ocenie infrastruktury turystycznej główną trudność stanowiło sprowadzenie do wspólnego mianownika wartości opisujących różne jej cechy (Wyrzykowski 2010). Dlatego wielkości liczbowe wszystkich przyjętych cech sprowadzono do określonej jednostki miary (m.in. Jafari 2001; Brzezińska-Wójcik, Skowronek 2018), tj. do powierzchni każdego z 24 gubernatorstw w Tunezji.

W dalszej kolejności, w celu doprowadzenia cech o różnych mianach do ich porównywalności (Borys 1980), zastosowano metodę przekształcenia ilorazowego, przyjmując jako punkt odniesienia maksymalną wartość zmiennej. Cechy poddano normalizacji według poniższego wzoru (za Gołembski red. 1999):

$$
n_{i j}=y_{i j} / y_{\text {jmax }},
$$

gdzie:

$n$ - znormalizowana wartość stymulanty,

$y$ - wartość stymulanty (cechy),

$i$ - numer gubernatorstwa,

$j$ - numer kolejnej stymulanty (cechy).

Taki sposób postępowania spowodował, że wszystkie wartości zmiennych znormalizowanych należą do przedziału 0,0-1,0 (gdzie wartość 1,0 oznacza 
najwyższą atrakcyjność analizowanej cechy szczegółowej spośród wszystkich $\mathrm{w}$ analizowanych gubernatorstwach).

Tab. 1. Zestawienie przyjętych do analizy cech charakteryzujących zagospodarowanie turystyczne w gubernatorstwach Tunezji

Tab. 1. Summary of features characterizing tourism development adopted for analysis in the Tunisian governorates

\begin{tabular}{|c|c|c|c|c|}
\hline $\begin{array}{l}\text { Zagospodarowanie turystyczne } \\
\text { Tourism development }\end{array}$ & $\begin{array}{l}\text { Miara } \\
\text { Measure }\end{array}$ & \multicolumn{3}{|c|}{$\begin{array}{l}\text { Waga } \\
\text { Weight }\end{array}$} \\
\hline \multicolumn{4}{|c|}{ BAZA NOCLEGOWA } & 0,30 \\
\hline $\begin{array}{l}\text { Miejsca noclegowe (hotele, motele, } \\
\text { pensjonaty) }\end{array}$ & liczba / pow. gubernatorstwa w $\mathrm{km}^{2}$ & 1,00 & & \\
\hline \multicolumn{4}{|c|}{ BAZA GASTRONOMICZNA } & 0,30 \\
\hline $\begin{array}{l}\text { Podstawowe zakłady żywieniowe (restau- } \\
\text { racje, bary szybkiej obsługi, bary, bistra) }\end{array}$ & liczba / pow. gubernatorstwa w $\mathrm{km}^{2}$ & 1,00 & & \\
\hline \multicolumn{4}{|c|}{ BAZA KOMUNIKACYJNA } & 0,30 \\
\hline \multicolumn{3}{|c|}{ ZEWNĘTRZNA } & 0,50 & \\
\hline Lotniska & liczba / pow. gubernatorstwa $\mathrm{w} \mathrm{km}{ }^{2}$ & 0,70 & & \\
\hline Porty morskie & liczba / pow. gubernatorstwa $\mathrm{w} \mathrm{km}^{2}$ & 0,30 & & \\
\hline \multicolumn{3}{|c|}{ WEWNĘTRZNA } & 0,50 & \\
\hline Autostrady & $\mathrm{km} /$ pow. gubernatorstwa $\mathrm{w} \mathrm{km}^{2}$ & 0,50 & & \\
\hline $\begin{array}{l}\text { Drogi wewnętrzne (krajowe, regionalne, } \\
\text { lokalne) }\end{array}$ & $\mathrm{km} /$ pow. gubernatorstwa w $\mathrm{km}^{2}$ & 0,50 & & \\
\hline \multicolumn{2}{|c|}{ BAZA TOWARZYSZĄCA } & & & 0,10 \\
\hline \multicolumn{3}{|c|}{ INSTYTUCJE I URZĄDZENIA TURYSTYCZNO-REKREACYJNE } & 0,70 & \\
\hline Placówki kulturalne (muzea, teatry) & liczba / pow. gubernatorstwa w km² & 0,25 & & \\
\hline $\begin{array}{l}\text { Urządzenia rozrywkowe (parki wodne, } \\
\text { wesołe miasteczka, zoo, dyskoteki) }\end{array}$ & liczba / pow. gubernatorstwa w $\mathrm{km}^{2}$ & 0,25 & & \\
\hline $\begin{array}{l}\text { Urządzenia rekreacyjne (ośrodki talasso- } \\
\text { terapii, balneoterapii, Spa \& Wellness) }\end{array}$ & liczba / pow. gubernatorstwa w $\mathrm{km}^{2}$ & 0,25 & & \\
\hline $\begin{array}{l}\text { Urządzenia sportowe (pola golfowe, si- } \\
\text { łownie, stadiony, hale sportowe, baseny) }\end{array}$ & liczba / pow. gubernatorstwa w $\mathrm{km}^{2}$ & 0,25 & & \\
\hline \multicolumn{3}{|c|}{ INSTYTUCJE I URZĄDZENIA PARATURYSTYCZNE } & 0,30 & \\
\hline $\begin{array}{l}\text { Placówki ochrony zdrowia (szpitale, } \\
\text { kliniki, apteki) }\end{array}$ & liczba / pow. gubernatorstwa w $\mathrm{km}^{2}$ & 0,50 & & \\
\hline Placówki bankowe (banki) & liczba / pow. gubernatorstwa w $\mathrm{km}^{2}$ & 0,50 & & \\
\hline
\end{tabular}

Źródło: opracowanie własne.

Source: own study.

Otrzymanym wartościom znormalizowanym nadano wagi (tab. 1), posługując się propozycjami zawartymi w opracowaniach Gołembskiego (red. 1999) i Pawlusińskiego (2005). Suma wag wynosiła 1,00 dla każdego działu i każdej 
kategorii (tab. 1). Najwyższe wagi $(0,30)$ przyznano bazie noclegowej, gastronomicznej i komunikacyjnej, ponieważ mają podstawowe znaczenie dla gospodarki turystycznej (Pawlikowska-Piechotka 2009), w tym przypadku Tunezji. Bez tych elementów niemożliwy by był rozwój międzynarodowego ruchu turystycznego na analizowanym obszarze. $Z$ kolei charakter uzupełniający mają pozostałe urządzenia (Pawlusiński 2005), dla których wagę ustalono na 0,10 (tab. 1).

Do oceny bazy komunikacyjnej wybrano cztery elementy, które zostały zaliczone do dostępności zewnętrznej umożliwiającej dotarcie do obszaru recepcyjnego (lotniska - waga 0,70 ; porty morskie - waga 0,30 ) oraz do dostępności wewnętrznej ułatwiającej poruszanie się w jego granicach (autostrady - waga 0,50; drogi wewnętrzne, w tym krajowe, regionalne i lokalne - waga 0,50 ) (tab. 1). Wyższą wagę przyznano lotniskom, ponieważ jest to najpopularniejszy środek transportu wybierany przez turystów międzynarodowych (w tym Polaków) podróżujących do Tunezji.

W kolejnym etapie analizy, w celu zestandaryzowania pomiarów atrakcyjności, uzyskane wyniki syntetyczne dla każdej kategorii i każdego działu poddano ponownie normalizacji. Dzięki temu ostateczne syntetyczne wyniki atrakcyjności każdej kategorii i działu na analizowanym obszarze zostały zobiektywizowane, są porównywalne i mieszczą się w przedziale $0,000-1,000$. Uzyskane miary syntetyczne sklasyfikowano, używając przyjętego schematu - pięciostopniowej skali liczbowo-pojęciowej (tab. 2). Do utworzenia kryteriów klasyfikacji atrakcyjności infrastruktury turystycznej zastosowano metodę średnich arytmetycznych, która daje jednoznaczne i porównywalne odniesienie granic klas do zbioru wartości (Brzezińska-Wójcik, Skowronek 2018). Do wydzielenia granic pomiędzy poszczególnymi stopniami atrakcyjności turystycznej posłużyła przyjęta wielkość statystyczna - 0,250 (połowa wielkości średniej arytmetycznej dla zbioru).

Tab. 2. Kryteria klasyfikacji atrakcyjności infrastruktury turystycznej

Tab. 2. Criteria for classifying the attractiveness of tourist infrastructure

\begin{tabular}{|c|c|c|}
\hline $\begin{array}{c}\text { Wielkość wskaźnika } \\
\text { Size of the indicator }\end{array}$ & $\begin{array}{c}\text { Stopień atrakcyjności } \\
\text { Degree of attractiveness }\end{array}$ & $\begin{array}{c}\text { Interpretacja atrakcyjności } \\
\text { Interpretation of attractiveness }\end{array}$ \\
\hline$>0,751$ & 4 & Bardzo atrakcyjna \\
\hline $0,501-0,750$ & 3 & Atrakcyjna \\
\hline $0,251-0,500$ & 2 & Przeciętnie atrakcyjna \\
\hline $0,001-0,250$ & 1 & Mało atrakcyjna \\
\hline 0,000 & 0 & Nieatrakcyjna \\
\hline
\end{tabular}

Źródło: opracowanie własne na podstawie zasad zaproponowanych przez Warszyńską (1970).

Source: own study based on the principles proposed by Warszyńska (1970). 
Źródła danych dotyczące zagospodarowania turystycznego w Tunezji obejmowały materiały wtórne zgromadzone $\mathrm{w}$ oparciu o analizę danych pozyskanych: 1) z raportów, informatorów, biuletynów urzędów, 2) od instytucji prowadzących zestawienia statystyczne, m.in. Tunezyjskiego Urzędu ds. Turystyki Tunezji - O.N.T.T. (http://www.tourisme.gov.tn), Tunezyjskiego Narodowego Instytutu Statystycznego - I.N.S. (http://www.ins.nat.tn), Tunezyjskiego Ministerstwa ds. Turystyki i Sztuki (http://www.tourisme.gov.tn), Ministerstwa Mieszkalnictwa i Rozwoju Terytorialnego Republiki Tunezji (http://www.equipement.tn), 3) z portali turystycznych promujących Tunezję za pośrednictwem Tunezyjskiego Urzędu ds. Turystyki Tunezji (http://www.discovertunisia.com/ pl; http://www.kormoran.aplus.pl). W artykule, tam gdzie to było możliwe, zastosowano nazwy geograficzne według opracowania Nazewnictwo geograficzne świata (Komisja Standaryzacji Nazw Geograficznych Poza Granicami Polski przy Głównym Geodecie Kraju, Główny Urząd Geodezji i Kartografii 2004).

\section{ATRAKCYJNOŚĆ INFRASTRUKTURY TURYSTYCZNEJ TUNEZJI W ŚWIETLE WSKAŹNIKA SYNTETYCZNEGO}

Otrzymane wyniki umożliwiły klasyfikację jednostek administracyjnych Tunezji według trzech stopni atrakcyjności ich zagospodarowania turystycznego jako bardzo atrakcyjne, przeciętnie atrakcyjne oraz mało atrakcyjne, zgodnie z zasadą przyjętą w tab. 2 .

Wśród obszarów uznanych za bardzo atrakcyjne (czwarty stopień atrakcyjności) znalazło się tylko gubernatorstwo Tunis (wartość wskaźnika 1,000). Złożyły się na to maksymalne wartości atrakcyjności turystycznej określone dla wszystkich czterech składowych infrastruktury, tj. dla baz: noclegowej $(1,000)$, gastronomicznej (1,000), komunikacyjnej $(1,000)$ i towarzyszącej $(1,000)$ (ryc. 2).

$\mathrm{Na}$ wysoką ocenę bazy komunikacyjnej w gubernatorstwie Tunis wpłynęły maksymalne wartości wskaźników $(1,000)$ obliczone dla obu składowych - komunikacji zewnętrznej i wewnętrznej (tab. 3).

Ocena bazy towarzyszącej jako bardzo atrakcyjnej w gubernatorstwie Tunis wynika z uzyskanych maksymalnych wielkości $(1,000)$ wskaźników dla wszystkich 19 elementów w ramach dwóch głównych grup urządzeń należących do bazy uzupełniającej: instytucji i urządzeń turystyczno-rekreacyjnych $(1,000)$ oraz instytucji i urządzeń paraturystyczych $(1,000)$ (tab. 4). Obiekty te dają więc możliwość korzystania z najszerszego zakresu usług związanych z potrzebami turystów.

Ocenę przeciętnie atrakcyjną (drugi stopień) w zakresie infrastruktury turystycznej uzyskało gubernatorstwo Monastur $(0,302)$ (ryc. 2). Na ostateczną wielkość wskaźnika na tym obszarze miały wpływ wielkości wskaźników uzyskane 


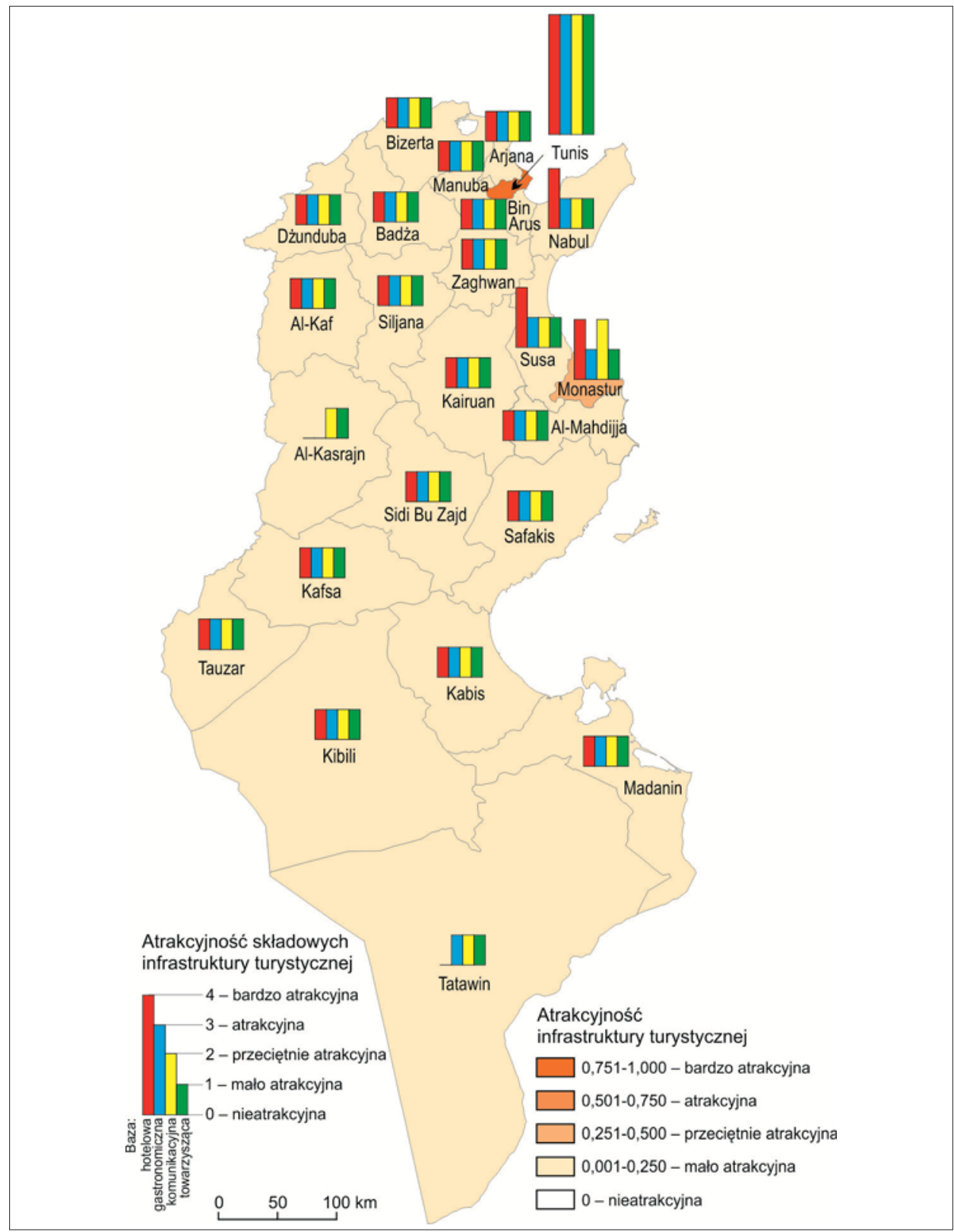

Ryc. 2. Atrakcyjność infrastruktury turystycznej Tunezji oraz jej elementów składowych (bazy hotelowej, gastronomicznej, komunikacyjnej, towarzyszącej) Źródło: opracowanie własne.

Fig. 2. The attractiveness of Tunisia's tourist infrastructure and its constituent elements (hotel, gastronomic, transport and accompanying facilities)

Source: own study. 
Tab. 3. Znormalizowane wielkości cech bazy komunikacyjnej w gubernatorstwach Tunezji Tab. 3. Standardized size of the communication base features in the Tunisian governorates

\begin{tabular}{|c|c|c|c|c|}
\hline \multirow{2}{*}{$\begin{array}{c}\text { Gubernatorstwo } \\
\text { Governorate }\end{array}$} & \multicolumn{2}{|c|}{$\begin{array}{l}\text { Dostępność zewnętrzna } \\
\text { External availability }\end{array}$} & \multicolumn{2}{|c|}{$\begin{array}{l}\text { Dostępność wewnętrzna } \\
\text { Internal availability }\end{array}$} \\
\hline & $\begin{array}{l}\text { lotniska } \\
\text { airports }\end{array}$ & $\begin{array}{l}\text { porty morskie } \\
\text { seaports }\end{array}$ & $\begin{array}{l}\text { autostrady } \\
\text { highways }\end{array}$ & $\begin{array}{l}\text { drogi wewnętrzne } \\
\text { internal roads }\end{array}$ \\
\hline Al-Kaf & 0,000 & 0,000 & 0,000 & 0,278 \\
\hline Al-Kasrajn & 0,000 & 0,000 & 0,000 & 0,014 \\
\hline Al-Mahdijja & 0,000 & 0,195 & 0,082 & 0,309 \\
\hline Arjana & 0,000 & 0,000 & 0,101 & 0,683 \\
\hline Badża & 0,000 & 0,000 & 0,318 & 0,341 \\
\hline Bin Arus & 0,000 & 0,365 & 0,080 & 0,672 \\
\hline Bizerta & 0,077 & 0,077 & 0,213 & 0,391 \\
\hline Dżunduba & 0,093 & 0,000 & 0,276 & 0,268 \\
\hline Kabis & 0,040 & 0,121 & 0,000 & 0,181 \\
\hline Kafsa & 0,037 & 0,000 & 0,000 & 0,060 \\
\hline Kairuan & 0,000 & 0,000 & 0,000 & 0,196 \\
\hline Kibili & 0,000 & 0,000 & 0,050 & 0,032 \\
\hline Madanin & 0,031 & 0,251 & 0,000 & 0,427 \\
\hline Manuba & 0,000 & 0,000 & 0,081 & 0,719 \\
\hline Monastur & 0,281 & 0,000 & 0,000 & 0,908 \\
\hline Nabul & 0,000 & 0,406 & 0,111 & 0,403 \\
\hline Safakis & 0,038 & 0,076 & 0,210 & 0,089 \\
\hline Sidi Bu Zajd & 0,000 & 0,000 & 0,129 & 0,112 \\
\hline Siljana & 0,000 & 0,000 & 0,163 & 0,224 \\
\hline Susa & 0,108 & 0,216 & 0,115 & 0,402 \\
\hline Tatawin & 0,015 & 0,000 & 0,000 & 0,067 \\
\hline Tauzar & 0,051 & 0,000 & 0,000 & 0,171 \\
\hline Tunis & 1,000 & 1,000 & 1,000 & 1,000 \\
\hline Zaghwan & 0,000 & 0,000 & 0,000 & 0,000 \\
\hline
\end{tabular}

Źródło: opracowanie własne.

Source: own study.

dla baz hotelowej $(0,480)$ i komunikacyjnej $(0,326)$, określone jako przeciętnie atrakcyjne, a także wartości oceny baz gastronomicznej $(0,146)$ i towarzyszącej $(0,168)$, określone jako mało atrakcyjne (ryc. 2).

Przeważającą grupę (22) stanowiły te gubernatorstwa, w których infrastruktura turystyczna została oceniona jako mało atrakcyjna (pierwszy stopień). Najniższą wartość w tym zakresie uzyskało gubernatorstwo Al-Kasrajn $(0,001)$, 
Tab. 4. Znormalizowane wielkości cech opisujących bazę towarzyszącą w gubernatorstwach Tunezji Tab. 4. Standardized sizes of features describing the accompanying base in the governorates of Tunisia

\begin{tabular}{|c|c|c|}
\hline $\begin{array}{c}\text { Gubernatorstwo } \\
\text { Governorate }\end{array}$ & $\begin{array}{l}\text { Instytucje i urządzenia turystyczno- } \\
\text {-rekreacyjne } \\
\text { Tourist and recreation institutions } \\
\text { and devices }\end{array}$ & $\begin{array}{l}\text { Instytucje i urządzenia paraturystyczne } \\
\text { Paraturist institutions and devices }\end{array}$ \\
\hline Al-Kaf & 0,009 & 0,005 \\
\hline Al-Kasrajn & 0,001 & 0,000 \\
\hline Al-Mahdijja & 0,017 & 0,017 \\
\hline Arjana & 0,083 & 0,178 \\
\hline Badża & 0,006 & 0,008 \\
\hline Bin Arus & 0,081 & 0,142 \\
\hline Bizerta & 0,010 & 0,019 \\
\hline Dżunduba & 0,022 & 0,012 \\
\hline Kabis & 0,005 & 0,007 \\
\hline Kafsa & 0,005 & 0,004 \\
\hline Kairuan & 0,010 & 0,007 \\
\hline Kibili & 0,006 & 0,001 \\
\hline Madanin & 0,093 & 0,008 \\
\hline Manuba & 0,024 & 0,040 \\
\hline Monastur & 0,196 & 0,102 \\
\hline Nabul & 0,047 & 0,046 \\
\hline Safakis & 0,006 & 0,022 \\
\hline Sidi Bu Zajd & 0,006 & 0,004 \\
\hline Siljana & 0,010 & 0,004 \\
\hline Susa & 0,073 & 0,047 \\
\hline Tatawin & 0,000 & 0,001 \\
\hline Tauzar & 0,007 & 0,003 \\
\hline Tunis & 1,000 & 1,000 \\
\hline Zaghwan & 0,007 & 0,008 \\
\hline
\end{tabular}

Źródło: opracowanie własne.

Source: own study.

a najwyższą - Susa $(0,203)$. Na najniższą wielkość wskaźnika uzyskaną w gubernatorstwie Al-Kasrajn wpływ miały wartości uzyskane dla dwóch działów, tj. dla bazy hotelowej oraz bazy gastronomicznej. Otrzymane wartości indykatorów wyniosły 0,000 . Pozostałe dwie bazy - komunikacyjna oraz towarzysząca - uzyskały wielkości wskaźników odpowiednio 0,003 i 0,001, co daje im 
pierwszy stopień atrakcyjności (mało atrakcyjny). Natomiast w gubernatorstwie Susa za najwyższą wielkość wskaźnika syntetycznego w tym przedziale odpowiadała uzyskana wartość dla bazy hotelowej-0,395 (drugi stopień - przeciętnie atrakcyjny) oraz pierwszy stopień atrakcyjności dla pozostałych trzech działów, tj. bazy komunikacyjnej $(0,200)$, bazy towarzyszącej $(0,065)$ i bazy gastronomicznej $(0,061)$ (ryc. 2).

\section{DYSKUSJA}

Wyniki oceny wybranych cech infrastruktury turystycznej, przeprowadzonej metodą wielowymiarowej analizy porównawczej, pozwalają sklasyfikować Tunezję jako destynację generalnie mało atrakcyjną (wielkość wskaźnika syntetycznego wynosi tylko 0,109). Średnie wielkości liczbowe wskaźników syntetycznych uzyskanych dla wszystkich działów - baz: noclegowej, gastronomicznej, komunikacyjnej i towarzyszącej - wyniosły odpowiednio: 0,115, 0,066, 0,159 oraz 0,071 (ryc. 2), co pozwala ocenić je jako mało atrakcyjne.

Należy podkreślić, że Tunezja jest destynacją o charakterze wypoczynkowym, typu ,3-S” (Sea, Sun, Sand), którą turysta masowy kojarzy z pozytywnymi bodźcami związanymi z morzem, słońcem i piaszczystymi plażami. Oznacza to, że obszary niedysponujące takim zestawem walorów turystycznych (dostępem do plaż i morza) nie są celem jego podróży. Nic więc dziwnego, że w Tunezji regiony położone poza pasem wybrzeża mają słabiej rozbudowaną infrastrukturę do obsługi masowego ruchu turystycznego. Ten deficyt dostrzegalny jest w szczególności w 20 gubernatorstwach: od Bin Arus $(0,134)$ po Al-Kasrajn $(0,001)$. $\mathrm{W}$ jednostkach tych każdy z czterech działów infrastruktury został oceniony jako mało atrakcyjny (ryc. 2).

Najwyższy wskaźnik atrakcyjności infrastruktury turystycznej uzyskano dla gubernatorstwa Tunis $(1,000)$. Obszar ten może być zatem rekomendowany dla turysty masowego. Bardzo dobre warunki wypoczynku na tym terenie stwarzają rozbudowane bazy: noclegowa $(1,000)$, gastronomiczna $(1,000)$, komunikacyjna $(1,000)$ i towarzysząca $(1,000)$ (ryc. 2$)$.

$\mathrm{Na}$ wysoką ocenę bazy noclegowej $(1,000)$ w tym gubernatorstwie (ryc. 2) wpływają dwa czynniki: 1) około 48 miejsc noclegowych przypadających na $1 \mathrm{~km}^{2}$ powierzchni obszaru (według obliczeń na podstawie danych I.N.S.) oraz 2) występowanie najbardziej ekskluzywnych hoteli, w tym należących do prestiżowej grupy The Leading Hotels of the World (http://www.lhw.com). Ponadto miasto Tunis jest ważnym ośrodkiem turystycznym i biznesowym, dlatego obserwuje się popyt nie tylko na usługi noclegowe, lecz także na usługi żywieniowe. W związku z tym na bardzo wysoką ocenę bazy gastronomicznej 
w gubernatorstwie Tunis złożyła się najwyższa liczba (165) obiektów gastronomicznych w kraju. Na atrakcyjność kulinarną tego obszaru wpływa ich wielkość oraz różnorodność - od małych, kilkuosobowych restauracji po duże obiekty zbiorowego żywienia, jak również od kuchni regionalnej po kuchnie całego świata (w tym np. kuchnię marokańską, egipską, włoską, francuską, a nawet amerykańską). Na wysoką ocenę bazy komunikacyjnej $\mathrm{w}$ gubernatorstwie Tunis wpłynęły maksymalne wartości wskaźników $(1,000)$ obliczone dla obu składowych - komunikacji zewnętrznej i wewnętrznej (tab. 4). Duże znaczenie w tym zakresie mają porty lotnicze i morskie umożliwiające turyście w sposób łatwy i szybki dotarcie do interesujących go miejsc i obiektów. Sprzyja temu m.in. największy port lotniczy kraju - Tunis-Kartagina, obsługujący rocznie ponad $4 \mathrm{mln}$ pasażerów (http://www.aeroport-de-tunis-carthage.com), ale też port morski, obsługujący jednocześnie ruch handlowy i pasażerski. Na obszarze tego gubernatorstwa istnieje ponadto rozbudowana sieć krajowych połączeń komunikacyjnych pomiędzy wszystkimi miejscowościami.

Niestety, wysoki potencjał gubernatorstwa Tunis nie jest w pełni wykorzystywany, o czym świadczą wyniki badań Brzezińskiej-Wójcik i Widz (2017). Wynika z nich, że oferta skierowana do polskich turystów np. w 2017 r. nie obejmowała gubernatorstwa Tunis w pakietach pobytowych.

Niski poziom rozwoju bazy gastronomicznej w pozostałych gubernatorstwach spowodowany jest tym, że potrzeby żywieniowe turystów są zaspokajane w pierwszej kolejności przez obiekty noclegowe. Wynika to z popularnej wśród turystów formuły all inclusive, związanej z miejscem noclegu. Decyduje się na nią ok. 75\% wszystkich turystów (Raport Podróżnika 2016). W większości przypadków okazuje się ona tańsza niż samodzielne korzystanie z usług gastronomicznych poza hotelem. Opcja ta jest nie tylko atrakcyjna cenowo, lecz także wygodna ze względu na dostępność w jednym miejscu.

Pojawia się więc pytanie: Dlaczego Tunezja należy do najpopularniejszych destynacji, skoro ocena atrakcyjności infrastruktury turystycznej jest niska? Jednoznaczne udzielenie odpowiedzi jest skomplikowane. Po pierwsze, turystyczne preferencje co do kierunku podróży są zjawiskiem złożonym, trudnym do jednoznacznego i w pełni zestandaryzowanego objaśnienia. O atrakcyjności turystycznej obszaru, miejsca czy miejscowości decydują bowiem z jednej strony czynniki obiektywne (cechy przyrodnicze, kulturowe i społeczne oraz odpowiednie elementy infrastruktury turystycznej i paraturystycznej), a z drugiej strony - aspekt psychologiczny, subiektywne postrzeganie wszystkich czynników obiektywnych przez turystów. W niniejszym opracowaniu nie oceniano kompleksowo ani pierwszego, ani drugiego (psychologicznego) wymiaru atrakcyjności. Po drugie, spośród cech składających się na atrakcyjność turystyczną 
Tunezji najwyższą średnią wielkość wskaźnika syntetycznego $(0,561)$ uzyskały walory turystyczne, w tym walory wypoczynkowe $(0,523)$ (Widz 2019). Pod tym względem destynację tę generalnie można określić jako atrakcyjną turystycznie, która sprzyja wypoczynkowi o profilu,,3-S". Dotyczy to gubernatorstw na wybrzeżu, w północnej (Dżunduba, Badża, Bizerta, Arjana) oraz wschodniej (Bin Arus, Nabul, Susa, Al-Mahdijja, Safakis, Kabis, Madanin) części kraju. Jednak mimo sprzyjających walorów wypoczynkowych w obszarach tych infrastruktura turystyczna nie jest jeszcze dostatecznie rozwinięta.

Rodzi się zatem kolejne pytanie: Co może bezpośrednio wpłynąć na zwiększenie atrakcyjności infrastruktury turystycznej w gubernatorstwach położonych na wybrzeżu kraju? Być może będzie to możliwe za sprawą planowanych inwestycji wielkoskalowych („Sfax Taparura”, „Mediterranean Gate”, „The Financial Harbour - Tunis Bay") o wartości nawet 50 mld USD.

Program „Sfax Taparura” dotyczy przebudowy północnego nadbrzeża w gubernatorstwie Safakis, które na długości $3 \mathrm{~km}$ zostanie przekształcone w plażę. Ponadto $\mathrm{w}$ ramach tego projektu zostaną wybudowane hotele, tereny rekreacyjne, tereny zielone i obiekty użyteczności publicznej dla ok. 50 tys. osób (http:// ufmsecretariat.org/upfi-sfax-taparura-project).

Projekt „Mediterranean Gate” dotyczy osuszenia jeziora i terenów do niego przyległych na południe od Tunisu o łącznej powierzchni 836 ha. Ma tam zostać rozbudowana infrastruktura turystyczna - powstaną luksusowe hotele, port jachtowy, obiekty wypoczynkowe i sportowe, kawiarnie, restauracje oraz sale konferencyjne (http://www.goafrica.ecms.pl).

Ważny z turystycznego punktu widzenia jest też projekt „The Financial Harbour - Tunis Bay”, zlokalizowany w dzielnicy El Hsayène przy plaży Raoued w gubernatorstwie Arjana na północ od Tunisu (http://www.tunis-fh.com). Inwestycja zakłada wybudowanie - oprócz obiektów mieszkalnych - strefy turystyczno-rekreacyjnej (Krimi 2017).

\section{WNIOSKI}

Uzyskane rezultaty nie potwierdzają ogólnych, potocznych skojarzeń z Tunezją jako destynacją wypoczynkową o wysokim stopniu zagospodarowania turystycznego ze względu na przeważającą zorganizowaną turystykę masową. Znamienne jest to, że ocena infrastruktury turystycznej w gubernatorstwach obejmujących góry oraz półpustynne i pustynne obszary kraju wypada bardzo źle (baza hotelowa i gastronomiczna zostały ocenione jako nieatrakcyjne lub mało atrakcyjne). Są to bowiem obszary, które nie wpisują się w profil turystyki wypoczynkowej typu „3-S”. Otrzymanych wyników nie można jednak traktować 
jako jedynego wyznacznika szeroko pojmowanej atrakcyjności, gdyż stanowią one jedynie tło do dalszych rozważań nad podjętą problematyką. Oprócz dotychczasowych badań ilościowych ocena infrastruktury turystycznej Tunezji zostanie poszerzona o analizy w zakresie jakości i różnorodności oferowanych dóbr i usług z zastosowaniem innych metod, m.in. jakościowych (np. testu zróżnicowania semantycznego, metody flow-simplex, ASEB/SWOT, SERVPERF) (Kruczek 2011; Duda-Seifert 2015).

Podkreślić należy, że zastosowana metoda nie jest pozbawiona pewnych elementów subiektywizmu, np. przy doborze zmiennych czy nadaniu im wag, na co zwraca uwagę Gołembski (red. 2002). Niemniej uzyskane rezultaty wskazują na możliwość lepszego wykorzystania aktualnej infrastruktury turystycznej na niektórych obszarach Tunezji poprzez np. przygotowanie oferty pobytowej w gubernatorstwie Tunis, które cechuje najwyższy wskaźnik atrakcyjności zagospodarowania turystycznego.

Dodatkowo - przy założeniu, że zostaną sfinalizowane projekty „Sfax Taparura”, „Mediterranean Gate” oraz „The Financial Harbour - Tunis Bay” - poprawi się atrakcyjność infrastruktury w niektórych gubernatorstwach (Safakis, Bin Arus i Arjana). W konsekwencji wpłynie to na lepsze wykorzystanie cech ich środowiska geograficznego w sferze turystyki i rekreacji, które mogą oddziaływać na komfort wypoczynku turysty masowego.

\section{BIBLIOGRAFIA}

Borys T., 1980: Elementy teorii jakości. PWN, Warszawa.

Brzezińska-Wójcik T., Widz M., 2017: Ocena jakości pakietu turystycznego Tunezji przez polskich turystów metoda SERVPERF - studium przypadku. Turyzm, 27(2), 11-22. https://doi. org/10.18778/0867-5856.27.2.01

Brzezińska-Wójcik T., Skowronek E., 2018: Potencjalne i funkcjonalne obszary turystyczne na Roztoczu w świetle wyników wielowymiarowej analizy porównawczej - wyzwania i problemy metodyczne. Prace Geograficzne Instytutu Geografii i Gospodarki Przestrzennej UJ, (152), $33-53$.

Cohen E., 1972: Towards a sociology of international tourism. Social Research. Political Economics. The Johns Hopkins University Press, 39(1), 164-182.

Duda-Seifert M., 2015: Kryteria oceny atrakcyjności turystycznej obiektów architektury $w$ świetle literatury. Turystyka Kulturowa, (4), 74-87.

Duval D.T., 2007: Tourism and Transport: Modes, Networks and Flows. Channel View Publications, Clevendon-Buffalo-Toronto.

Dziechciarz J., 2003: Ekonometria. Metody, przykłady, zadania. Wyd. Akademii Ekonomicznej im. Oskara Langego we Wrocławiu, Wrocław.

Gaworecki W., 2003: Turystyka. PWE, Warszawa. 
Gołembski G. (red.), 1999: Regionalne aspekty rozwoju turystyki. PWN, Warszawa-Poznań.

Gołembski G. (red.), 2002: Metody stymulowania rozwoju turystyki w ujęciu przestrzennym. Wyd. Akademii Ekonomicznej w Poznaniu, Poznań.

Jafari J., 2001: The Scientification of Tourism, [w:] V.L. Smith, M. Brent (eds.), Hosts and Guests Revisited. Tourism Issues of the $21^{\text {st }}$ Century. Cognizant Communication Corporation, New York, 28-41.

Kaczmarek J., Stasiak A., Włodarczyk B., 2002: Produkt turystyczny. PWE, Warszawa.

Komisja Standaryzacji Nazw Geograficznych Poza Granicami Polski przy Głównym Geodecie Kraju, Główny Urząd Geodezji i Kartografii, 2004: Nazewnictwo geograficzne świata (Z. 3: Afryka). Warszawa.

Kowalczyk A., 2002: Geografia turyzmu. PWN, Warszawa.

Kowalczyk A., Derek M., 2010: Zagospodarowanie turystyczne. PWN, Warszawa.

Krimi A., 2017: Investissement: Le projet de Sama Dubaï sera-t-il enfin relancé? Kapitalis. http://kapitalis.com/tunisie/2017/03/20/investissement-le-projet-desamadubai-sera-t-il-enfin-relance

Kruczek Z., 2011: Atrakcje turystyczne. Fenomen, typologia, metody badań. Wyd. Proksenia, Kraków.

Lijewski T., Mikułowski B., Wyrzykowski J., 2002: Geografia turystyki Polski. PWE, Warszawa.

Liszewski S., 1995: Przestrzeń turystyczna. Turyzm, 5(2), 87-103.

Milewska M., Włodarczyk B., 2009: Hotelarstwo. Podstawowe wiadomości. PWE, Warszawa.

Milewski D., 2005: Regionalne uwarunkowania rozwoju turystyki na przykładzie województwa zachodniopomorskiego. Wyd. Naukowe Uniwersytetu Szczecińskiego, Szczecin.

Niezgoda A., 2013: Turystyka doświadczeń - dawna czy nowa forma turystyki?, [w:] R. Wiluś, J. Wojciechowska (red.), Nowe-stare formy turystyki w przestrzeni. Wyd. Uniwersytetu Łódzkiego, Łódź, 37-47. https://doi.org/10.18778/7525-925-4.04

Oppermann M., 1993: Tourism Space in Developing Countries. Annals of Tourism Research, 20(3), 535-556. https://doi.org/10.1016/0160-7383(93)90008-Q

Page S., 1995: Urban Tourism. Routledge, London-New York.

Page S., 2005: Transport and Tourism: Global Perspectives. Pearson Education, Harlow.

Pawlikowska-Piechotka A., 2009: Zagospodarowanie turystyczne i rekreacyjne. Wyd. Novae Res, Gdynia.

Pawlusiński R., 2005: Samorząd lokalny a rozwój turystyki. Przykład gmin Wyżyny Krakowsko-Częstochowskiej. Instytut Geografii i Gospodarki Przestrzennej UJ, Kraków.

Pawlusiński R., 2007. Transport w turystyce, [w:] W. Kurek (red.), Turystyka. PWN, Warszawa, $164-176$.

Płocka J., 2002: Wybrane zagadnienia z zagospodarowania turystycznego (Cz. I). Wyd. Centrum Kształcenia Ustawicznego, Toruń.

Rapacz A., Jaremen D.E., 2011: Atrakcyjność turystyczna jako czynnik wyboru destynacji turystycznej. Ekonomiczne Problemy Usług, 75, 131-141.

Raport Podróżnika 2016. https://www.travelplanet.pl/Content/pdf/dlamediow/raport_podroznika_2016_v02.pdf

Rogalewski O., 1979: Zagospodarowanie turystyczne. WSiP, Warszawa. 
Warszyńska J., 1970: Waloryzacja miejscowości z punktu widzenia atrakcyjności turystycznej (zarys metody). Prace Geograficzne UJ, 27, 103-113.

Warszyńska J., Jackowski A., 1979: Podstawy geografii turyzmu. PWN, Warszawa.

Widz M., 2019: Możliwości wykorzystania zasobów środowiska geograficznego Tunezji w kreowaniu oferty turystycznej (Rozprawa doktorska, Uniwersytet Marii Curie-Skłodowskiej w Lublinie). Lublin.

Widz M., Brzezińska-Wójcik T., 2016: Dynamika i cechy międzynarodowego ruchu turystycznego w Tunezji w latach 1960-2015. Ekonomiczne Problemy Turystyki, 35(3), 287-299. https:// doi.org/10.18276/ept.2016.3.35-23

Wyrzykowski J., 2010: Potencjat turystyczny w ujęciu geograficznym. Ekonomiczne Problemy Usług, 52, 33-42.

\section{ŹRÓDŁA INTERNETOWE}

http://ufmsecretariat.org/upfi-sfax-taparura-project

http://www.aeroport-de-tunis-carthage.com

http://www.discovertunisia.com/pl

http://www.equipement.tn

http://www.goafrica.ecms.pl

http://www.ins.nat.tn

http://www.kormoran.aplus.pl

http://www.lhw.com

http://www.tourisme.gov.tn

http://www.tunis-fh.com 